\title{
Optimization of Medium Ingredients for Keratinolytic Protease Production by Bacillus licheniformis MZK-03 using Statistical Experimental Designs
}

\author{
Mohammad Moniruzzaman, Alamgir Rahman and M Mozammel Hoq* \\ Department of Microbiology, University of Dhaka, Dhaka 1000, Bangladesh
}

[Received 04 April 2007; Accepted 21 April 2007]

\begin{abstract}
A culture medium was optimized for the production of keratinolytic protease by a newly isolated strain of Bacillus licheniformis MZK-03 in shake-flask culture. Based on the results of preliminary experiments, feather mill, molasses and trace elements were found to be major variables in keratinolytic protease production. The concentrations of these ingredients were optimized by using two statistical approaches, namely Box-Wilson method and central composite design. The optimized culture medium, finally determined by using the statistical approaches, composed of $0.95 \%$ feather mill, $0.12 \%$ molasses and $1.44 \%$ trace elements. The keratinolytic protease production was increased by approximately 2 -fold when the strain was grown in the optimized medium $(95.2 \mathrm{U} / \mathrm{ml})$ compared to the un-optimized medium $(56.05 \mathrm{U} / \mathrm{ml})$.
\end{abstract}

Keywords: Keratinolytic protease, Optimization, Bacillus licheniformis MZK-03, Statistical designs

\section{Introduction}

Keratins are the most abundant proteins in epithelial cells of vertebrates and represent the major constituents of skin and its appendages such as nail, hair, feather, and wool ${ }^{1}$. Keratins are fibrous and insoluble structural proteins extensively cross-linked with disulphide, hydrophobic, and hydrogen bonds ${ }^{2-3}$. Their high degree of cross-linking by disulfide bonds, hydrophobic interactions, and hydrogen bonds stabilizes keratin filament structure $^{1}$. Therefore, keratinous material is water insoluble and extremely resistant to degradation by proteolytic enzymes such as trypsin, pepsin and papain ${ }^{1-2}$.

A group of proteolytic enzymes which are able to hydrolyze insoluble keratins more efficiently than other proteases are called keratinases ${ }^{2}$. They are produced by some insects and mostly by microorganisms. The best studied are keratinases from the dermatophytic genera Microsporum ${ }^{4}$ and Trichophyton ${ }^{5}$ as well as from bacteria of the genera Bacillus ${ }^{6-11}$ and Streptomyces ${ }^{12}$. Bacterial keratinases are of particular interest because of they act on insoluble keratins with a broad range of protein substrates ${ }^{13}$. These enzymes have been studied for dehairing processes in the leather industry ${ }^{14}$ and hydrolysis of feather keratin ${ }^{13}$, which is a by-product generated in huge amounts by the poultry industry. Feather hydrolysates produced by bacterial keratinases have been used as additives for animal feed ${ }^{1,15-16}$. In addition, keratin hydrolysates have potential use as organic fertilizers, production of edible films and rare amino acids ${ }^{17-18}$.

Some of the important strains Bacillus licheniformis are used as a tool in industrial biotechnology to manufacture enzymes, antibiotics, biochemicals and consumer products ${ }^{6-7,13}$. All of them exhibit keratinolytic activities by extracellular enzymes. A strain of Bacillus licheniformis MZK-03 has been previously isolated from Bangladesh ${ }^{19}$. It has been found to secrete a substantial amount of keratinolytic protease in the medium ${ }^{19}$, which can degrade the feather consisting mainly of $\beta$-keratin. Therefore, it has a promising future as source of keratinolytic proteases for use in poultry and leather industry of Bangladesh.

Cultivation conditions are essential in successful production of an enzyme, and optimization of parameters such as $\mathrm{pH}$, temperature and media composition are important in developing the cultivation process. Despite all the work that has been done on production of proteolytic enzymes, relatively little information is available on keratinases ${ }^{20}$. Optimization of medium by the classical method involves changing one independent variable while maintaining all others at a fixed level is extremely time consuming and expensive when a large number of variables are evaluated. To overcome this difficulty, experimental factorial design and response surface methodology can be employed to optimize the medium components. The statistical approaches like Box-Wilson method and central composite design have been previously used by several researchers for media ingredient optimization ${ }^{21-22}$. This paper reports on the optimization of some medium ingredient using the statistical techniques for production of keratinase by Bacillus licheniformis MZK-03.

\section{Materials and Methods}

Microorganisms and maintenances

The microorganism used was Bacillus licheniformis MZK-03. This organism was previously isolated from feather-decomposed soil collected from a local poultry farm in Dhaka, Bangladesh and

*Corresponding author:

Dr. M Mozammel Hoq, Professor, Department of Microbiology, University of Dhaka, Dhaka 1000, Bangladesh

Tel (Office): (02) 9661920-73/7734; Fax: +880 (02) 8615583; E-mail: mhoq@univdhaka.edu 
identified using $16 \mathrm{~S}$ rRNA typing by the International Centre for Biotechnology, Osaka University, Japan ${ }^{19}$. Stock culture of the organism was maintained at $-70^{\circ} \mathrm{C}$ in nutrient broth containing $10 \%$ glycerol.

\section{Enzyme production}

A single colony from the agar plate was aseptically transferred to $50 \mathrm{ml}$ nutrient broth in 250-ml Erlenmeyer flask. The flask was incubated for $7-8 \mathrm{~h}$ at $37^{\circ} \mathrm{C}$ and $200 \mathrm{rpm}$ in an orbital shaker until it reached to an absorbance of 0.5-0.8 at $600 \mathrm{~nm}$. To induce enzyme production $5 \mathrm{ml}$ of the seed culture was transferred to $95 \mathrm{ml}$ of feather degrading enzyme-producing broth in a 500-ml Erlenmeyer flask. The feather degrading enzyme-producing broth contained $0.75 \mathrm{~g} / \mathrm{NaCl}, 0.09 \mathrm{~g} / \mathrm{l} \mathrm{CaCl}{ }_{2}, 1.50 \mathrm{~g} / \mathrm{l} \mathrm{MgCl}{ }_{2} \cdot 6 \mathrm{H}_{2} \mathrm{O}, 1.05 \mathrm{~g} / \mathrm{KH}_{2} \mathrm{PO}_{4}$ and $2.10 \mathrm{~g} / \mathrm{K} \mathrm{K}_{2} \mathrm{HPO}_{4}$ supplemented with $1 \%$ feather mill corresponding to $10 \mathrm{~g} / \mathrm{l}$ (initial $\mathrm{pH}$ 7.5). The inoculated flasks were incubated at $37^{\circ} \mathrm{C}$ at $150 \mathrm{rpm}$ in an orbital shaker unless otherwise stated. Crude enzyme was collected after $42 \mathrm{~h}$ of incubation by centrifuging at 5,000 $\mathrm{rpm}$ for $10 \mathrm{~min}$. The supernatant was preserved at $4^{\circ} \mathrm{C}$ and assayed for enzymes and protein (in duplicate).

\section{Protein and enzyme assay}

Soluble protein in the culture supernatant was estimated according to the Bradford method using bovine serum albumin (BSA) as standard ${ }^{23}$. Keratinolytic protease activity was determined by azocasein (Sigma, USA) hydrolysis method ${ }^{24}$ with some modifications and the method has been described previously ${ }^{25}$. One unit of enzyme activity was defined as an increase of 0.01 absorbance unit per min at $440 \mathrm{~nm}$ under the assay conditions.

\section{Experimental design}

Based on the results obtained in preliminary experiments, feather mill, molasses and trace element solution were found to be major variables in the keratinolytic protease production. Hence, these variables were selected to find the optimized conditions for higher keratinolytic protease production using two well known statistical methods namely, Box-Wilson Method ${ }^{26}$ and central composite design ${ }^{27-29}$.

According to the Box-Wilson Experimental method if the proportions of three ingredients $x_{1}, x_{2}$ and $x_{3}$ are to be optimized and $y$ is the yield, then $\mathrm{y}$ can be related to the three ingredients as follows:

$y=b_{o}+b_{1} x_{1}+b_{2} x_{2}+b_{3} x_{3}+b_{12} x_{1} x_{2}+b_{13} x_{1} x_{2}+b_{13} x_{1} x_{3}+$ $b_{23} x_{2} x_{3}+b_{11} x_{1}^{2}+b_{22} x_{1}^{2}+b_{33} x_{1}^{2} \cdots \cdots$

$b$ represents the regression coefficients. If yield is taken to be the surface of a mountain, the method explores a small part of the yield surface, in which the linear function equation, $y=b_{o}+b_{1} x_{1}+b_{2} x_{2}$ $+b_{3} x_{3}$, is calculated. Computer software Statistica edition 99 (StatSoft Inc) was used to map contours of the whole yield surface.

In the first experiment of the Box-Wilson Method, which begins at some distance from the yield summit, the regression coefficient $b$ was determined or the direction of the steepest slope to the summit was established. The goal was to optimize a medium containing feather mill, molasses and trace elements. In the first step a factorial experiment is designed in which two levels of feather mill, molasses and trace elements are used. Both levels of each were run in combination with all the others. The levels chosen varied the same amount above and below a chosen mean. The results from this experiment indicated how much the concentrations of each ingredient should be increased or decreased proportionally in the next experiment. In the second experiment, by changing the levels of the medium ingredients in accordance with the obtained regression coefficient values the 'ascent' was actually made. Finally, the medium was optimized by using a central composite design, which is basically a two factor experimental design where each factor is studied at three levels. After completion of the experiment, the optimum concentration of each nutrient was calculated using defined statistical equations.

\section{Results and Discussion}

Keratinolytic proteases are found frequently in fungi (Trychophyton mentagrophytes, Tryychophyton rubrum) ${ }^{30}$, actinomycetes (Streptomyces spp.) and bacteria (Bacillus subtilis, Bacillus licheniformis, Bacillus cereus, Brevibacillus borstelensis $^{31}$. Keratinolytic protease production by Bacillus licheniformis was carried out in a feather mill medium containing feather mill, molasses and trace elements $\left(\mathrm{NaCl}, \mathrm{CaCl}_{2}\right.$, $\mathrm{MgCl}_{2} \cdot 6 \mathrm{H}_{2} \mathrm{O}, \mathrm{K}_{2} \mathrm{HPO}_{4}$, and $\mathrm{KH}_{2} \mathrm{PO}_{4}$ ). Preliminary experiments demonstrated the best effects at $1 \%$ feather mill, $1.5 \%$ trace element, and $0.10 \%$ molasses. This was the base level ingredient concentration used for our experiment.

The concentrations of the ingredients like feather mill, trace element and molasses were then optimized using Box-Wilson method $^{32}$. This method is a factorial design which consists of two sets of experiments. The first step (Table 1) consists of running two steps of each factor in combination with all others. Total eight combinations were possible. The levels chosen were varied in same amount above or below the base levels. The upper limit has an assigned value of +1 and lower limit has a value of -1 .

Table 1. Experimental design for optimization of ingredient concentrations for keratinolytic protease production by Bacillus licheniformis MZK-03 using Box-Wilson method and the results obtained

\begin{tabular}{|c|c|c|c|c|c|}
\hline \multirow[t]{2}{*}{ Ingredient } & \multicolumn{3}{|c|}{ Experimental design } & \multicolumn{2}{|c|}{ Results obtained } \\
\hline & $\begin{array}{l}\text { Feather } \\
\text { mill } \\
(\%)\end{array}$ & $\begin{array}{l}\text { Trace } \\
\text { element } \\
(\%)\end{array}$ & $\begin{array}{c}\text { Molasses } \\
(\%)\end{array}$ & $\begin{array}{c}\text { Keratinolytic } \\
\text { protease } \\
(\mathrm{U} / \mathrm{ml})\end{array}$ & $\begin{array}{c}\text { Final } \\
\mathrm{pH}\end{array}$ \\
\hline Lower level & 0.75 & 1 & 0.05 & & \\
\hline Upper level & 1.25 & 2 & 0.15 & & \\
\hline Base level & 1 & 1.5 & 0.10 & & \\
\hline Coding unit $( \pm)$ & 0.25 & 0.50 & 0.05 & & \\
\hline Medium No. 1 & $0.75(-)$ & $1(-)$ & $0.05(-)$ & 57.50 & 8.75 \\
\hline 2 & $0.75(-)$ & $2(+)$ & $0.05(-)$ & 48.20 & 8.22 \\
\hline 3 & $0.75(-)$ & $1(-)$ & $0.15(+)$ & 45.00 & 8.72 \\
\hline 4 & $0.75(-)$ & $2(+)$ & $0.15(+)$ & 49.50 & 8.27 \\
\hline 5 & $1.25(+)$ & $1(-)$ & $0.05(-)$ & 47.00 & 9.00 \\
\hline 6 & $1.25(+)$ & $2(+)$ & $0.05(-)$ & 46.50 & 8.53 \\
\hline 7 & $1.25(+)$ & $1(-)$ & $0.15(+)$ & 54.70 & 8.79 \\
\hline 8 & $1.25(+)$ & $2(+)$ & $0.15(+)$ & 50.00 & 8.58 \\
\hline
\end{tabular}


The base levels and coding units were selected based on the results obtained in preliminary experiments carried out before. Only keratinolytic protease yields were considered for the determination of slope $b$ or regression coefficient. The calculated values gave an indication of increasing molasses concentration by $0.02 \%$, and decreasing feather mill and trace element by $0.1 \%$ and $0.3 \%$ respectively from the corresponding base level.

The second experiment to obtain the 'ascent' yielded results in accordance with Table 2. The yield plateau with respect to keratinolytic protease was reached at medium No. 2 containing $0.9 \%$ feather mill, $0.12 \%$ molasses and $1.2 \%$ trace element. The enzyme activity in this medium was $58.55 \mathrm{U} / \mathrm{ml}$. The results obtained in this experiment indicated a gradual decrease of keratinolytic protease production with progressively decreasing feather mill and trace element, and increasing molasses concentration. This could be due to low mineral element concentration and increasing reducing sugar level ${ }^{27}$ from molasses.

Table 2. Second experimental design of Box-Wilson method to obtain the 'ascent' and the results obtained

\begin{tabular}{lllccccc}
\hline Parameter & \multicolumn{3}{c}{ Experimental design } & & \multicolumn{2}{c}{ Results obtained } \\
\cline { 2 - 4 } \cline { 7 - 8 } Ingredients & $\begin{array}{c}\text { Feather } \\
\text { mill } \\
(\%)\end{array}$ & $\begin{array}{c}\text { Trace } \\
\text { element } \\
(\%)\end{array}$ & $\begin{array}{c}\text { Molasses } \\
(\%)\end{array}$ & & $\begin{array}{c}\text { Keratinolytic } \\
\text { protease } \\
(\mathrm{U} / \mathrm{ml})\end{array}$ & $\begin{array}{c}\text { Final } \\
\mathrm{pH}\end{array}$ \\
\hline Medium No. & 1 & 1.0 & 1.5 & 0.10 & & 57.85 & 7.65 \\
& 2 & 0.9 & 1.2 & 0.12 & & 58.55 & 7.61 \\
& 3 & 0.8 & 0.9 & 0.14 & & 56.75 & 7.73 \\
4 & 0.7 & 0.6 & 0.16 & & 53.65 & 7.77 \\
5 & 0.6 & 0.3 & 0.18 & & 47.15 & 7.63 \\
6 & 0.5 & 0.0 & 0.20 & & 32.75 & 7.63 \\
7 & 0.4 & 0.0 & 0.22 & & 25.60 & 7.47 \\
8 & 0.3 & 0.0 & 0.24 & & 20.80 & 7.23 \\
\hline
\end{tabular}

It was evident that feather mill and trace element were the most important factors for keratinolytic protease production. So the optimal concentrations of these two major components were optimized using a $3^{2}$ central composite design ${ }^{27-29}$. The results are given in Table 3. The optimum concentration of each nutrient was calculated using the following second order equations:

$x_{1}=\frac{b_{2} b_{12}-2 b_{1} b_{22}}{4 b_{11} b_{22}-b_{12}^{2}}$

and

$x_{2}=\frac{b_{2} b_{12}-2 b_{2} b_{11}}{4 b_{11} b_{22}-b_{12}^{2}}$

where, $x_{1}$ and $x_{2}$ are variables, namely feather mill and trace element solution, respectively, $b_{0}=$ constant, $b_{1}$ and $b_{2}=$ linear coefficients, $b_{12}=$ cross product coefficient, $b_{11}$ and $b_{22}=$ quadric coefficients. The response surface diagram (Figure 1) generated from these statistical analyses was used to calculate the most appropriate concentrations of feather mill and trace element.
Table 3. Experimental design for optimization of feather mill and trace element concentration for keratinolytic protease production using $3^{2}$ central composite design and the results obtained

\begin{tabular}{|c|c|c|c|c|}
\hline \multirow{2}{*}{$\begin{array}{l}\text { Parameter } \\
\text { obtained }\end{array}$} & \multicolumn{2}{|c|}{ Variable (\%) } & \multicolumn{2}{|c|}{ Result } \\
\hline & $\begin{array}{c}\text { Feather } \\
\text { mill } \\
\left(\mathrm{x}_{1}\right)\end{array}$ & $\begin{array}{c}\text { Trace } \\
\text { element } \\
\left(\mathrm{x}_{2}\right)\end{array}$ & $\begin{array}{c}\text { Keratinolytic } \\
\text { protease } \\
(\mathrm{U} / \mathrm{ml})\end{array}$ & $\begin{array}{c}\text { Final } \\
\mathrm{pH}\end{array}$ \\
\hline Lower level & 0.8 & 0.9 & & \\
\hline Upper level & 1 & 1.5 & & \\
\hline Central level & 0.9 & 1.2 & & \\
\hline Medium No. 1 & $1(+)$ & $1.5(+)$ & 56.05 & 8.05 \\
\hline 2 & $1(+)$ & $1.2(0)$ & 56.10 & 8.18 \\
\hline 3 & $1(+)$ & $0.9(-)$ & 53.10 & 8.26 \\
\hline 4 & $0.9(0)$ & $1.5(+)$ & 54.80 & 8.00 \\
\hline 5 & $0.9(0)$ & $1.2(0)$ & 56.00 & 8.02 \\
\hline 6 & $0.9(0)$ & $0.9(-)$ & 54.35 & 8.31 \\
\hline 7 & $0.8(-)$ & $1.5(+)$ & 59.10 & 7.99 \\
\hline 8 & $0.8(-)$ & $1.2(0)$ & 56.80 & 8.18 \\
\hline 9 & $0.8(-)$ & $0.9(-)$ & 56.45 & 8.19 \\
\hline
\end{tabular}

The $x_{1}$ and $x_{2}$ values were determined according to following equations:

$$
\begin{aligned}
x_{1} & =\frac{b_{2} b_{12}-2 b_{1} b_{22}}{4 b_{11} b_{22}-b_{12}^{2}} \\
& =\frac{(1.008)(0.075)-2(-1.183)(-0.643)}{4(1.2335)(-0.643)-0.075} \\
& =0.445 \text { (approximately) }
\end{aligned}
$$

Variable: Feather mill $\left(x_{1}\right)$

The calculated feather mill concentration:

Base level + variation from base level $\times x_{1}$ value $=0.9+0.1 \times 0.445$ $=0.9445$ H” $0.95 \%$ (approximately)

$$
\begin{aligned}
x_{2} & =\frac{b_{2} b_{12}-2 b_{2} b_{11}}{4 b_{11} b_{22}-b_{12}^{2}} \\
& =\frac{(-1.183)(0.075)-2(-1.008)(1.2335)}{4(1.2335)(-0.643)-0.075} \\
& =0.79 \text { (approximately). }
\end{aligned}
$$

Variable: Trace element $\left(x_{2}\right)$

The calculated trace element concentration: Base level + variation from base level $\times x_{2}$ value $=1.2+0.3 \times 0.79=1.4379 \mathrm{H}^{\prime} 1.44 \%$ (approximately). 


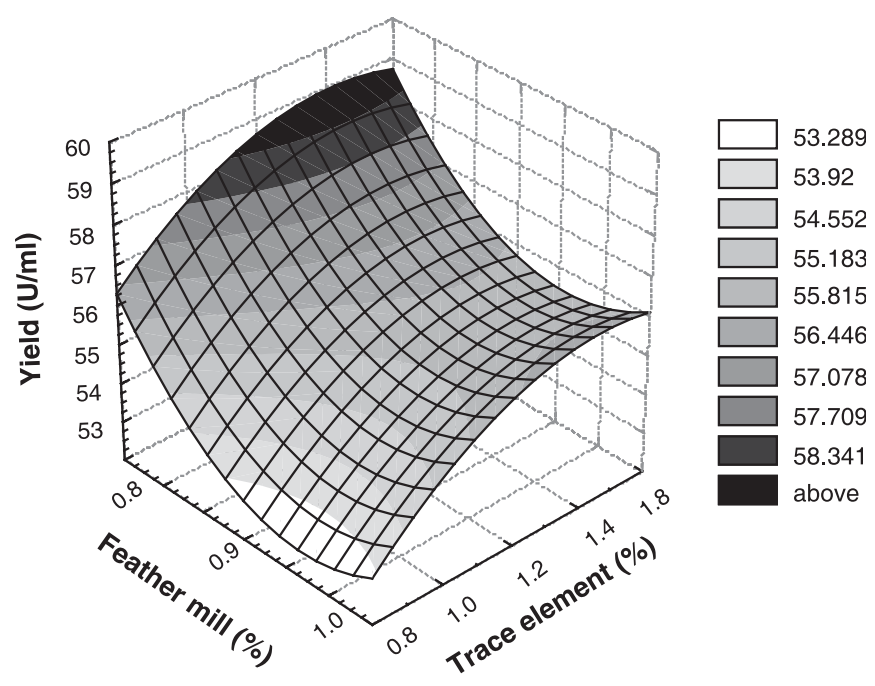

Figure 1. 3-D graphical representation of the response surface for enzyme yield generated by the central composite design.

The optimum response analyzed by response surface statistical analysis was identified as $0.95 \%$ feather mill and $1.44 \%$ trace element, which corresponded to keratinolytic protease activity of $95.2 \mathrm{U} / \mathrm{ml}$ (average value obtained from five separate cultures). The base level medium showed $56.05 \mathrm{U} / \mathrm{ml}$ of enzyme activity. So the enzyme activity in the optimized medium was remarkably higher than that in base level medium. The optimized medium thus developed contained only few cheap components as feather mill (0.95\%), molasses (0.12\% ), $\mathrm{NaCl}(0.072 \%), \mathrm{CaCl}_{2}(0.086 \%)$, $\mathrm{MgCl}_{2} \cdot 6 \mathrm{H}_{2} \mathrm{O}\left(0.0144 \%\right.$ ) and $\mathrm{KH}_{2} \mathrm{PO}_{4}+\mathrm{K}_{2} \mathrm{HPO}_{4}(1: 2$ ratio, $0.10 \%)$. Thus, the medium seems economically feasible for large-scale production of keratinolytic protease by Bacillus licheniformis MZK-03.

Keratinolytic protease is a promising enzyme in several industrial sectors. At poultry processing plants, feathers are produced in huge amounts reaching millions of tons per year worldwide ${ }^{33}$. Feathers, mainly constituted of pure keratin are utilized on a limited extent as dietary protein supplement for animal feed because feather mill production is an expensive chemical process requiring significant amount of energy. It also results in a product of poor digestibility and variable nutrient quality ${ }^{34}$. Microorganismderived keratinolytic protease can be a suitable alternative for carrying out feather mill production. On the other hand, keratinolytic protease produced by microorganisms can reduce the cost and complexity of poultry waste and effluent treatment, amino acid production, bating and dehairing in leather industry.

It is apparent from this study that Bacillus licheniformis MZK-03 is a potent producer of keratinolytic enzyme while grown on readily available and cheap substrate in submerges cultivations. Optimization of the medium by two sophisticated statistical approaches certainly increases the efficiency of enzyme production. This experiment finely identified the optimum requirements and fulfilled the requirements of stringent optimization of keratinolytic production medium. The findings of this experiment could significantly contribute to biotechnological application of microorganism derived keratinolytic protease as a widely used enzyme.

\section{Acknowledgement}

Financial support from the Ministry of Science and Information \& Communication Technology, Government of People's Republic of Bangladesh is acknowledged.

\section{References}

1. Fuchs E. 1995. Keratins and the skin. Annu Rev Cell Dev. 11: 123-153.

2. Onifade AA, Al-Sane NA, Al-Musallam AA \& Al-Zarban S. 1998. A review: Potentials for biotechnological applications of keratin degrading microorganisms and their enzymes for nutritional improvement of feathers and other keratins as livestock feed resources. Bioresource Technol. 66(1): 1-11.

3. Ramnani P \& Gupta R. 2004. Optimization of media component for keratinase production on feather by Bacillus licheniformis RGI using stastical methods involving response surface methodology. Biotechno Appl Biochem. 40: 191-196.

4. Mignon B, Swinnen M, Bouchara JP, Hofinger M, Nikkles A, Pierard G, Gerday C \& Losson B. 1998. Purification and characterization of a $31.5 \mathrm{kDa}$ keratinolytic subtilizin-like serine protease from Microsporum canis and evidence of its secretion in naturally infected cats. Med Mycol. 36: 395-404.

5. Qin LM, Dekio S \& Jidoi J. 1992. Some biochemical characteristics of a partially purified extracellular keratinase from Trichophyton schoenleinii. Zentralbl Bakteriol. 277: 236-244.

6. Cheng SW, Hu HM, Shen SW, Takagi H, Asano M \& Tsai YC. 1995. Production and characterization of keratinase of a feather-degrading Bacillus licheniformis PWD-1. Biosci Biotechnol Biochem. 59: 2239-2243.

7. Lin X, Kelemen DW, Miller ES \& Shih JCH. 1995. Nucleotide sequence and expression of kerA, the gene encoding a keratinolytic protease of Bacillus licheniformis PWD-1. Appl Environ Microbiol. 61: 14691474 .

8. Han XQ \& Damodaran S. 1998. Purification and characterization of Protease Q: A detergent- and urea-stable serine endopeptidase from Bacillus pumilus. J Agric Food Chem. 46: 3596-3603.

9. Lee H, Suh DB, Hwang JH \& Suh HJ. 2002. Characterization of a keratinolytic metalloprotease from Bacillus sp. SCB-3. Appl Biochem Biotechnol. 97: 123-133.

10. Suh HJ \& Lee HK. 2001. Characterization of a keratinolytic serine protease from Bacillus subtilis KS-1. J Protein Chem. 20: 165-169.

11. Suntornsuk W \& Suntornsuk L. 2003. Feather degradation by Bacillus sp. FK 46 in submerged cultivation. Bioresour Technol. 86: 293-243.

12. Bressollier P, Letourneau F, Urdaci M \& Verneuil B. 1999. Purification and characterization of a keratinolytic serine proteinase from Streptomyces albidoflavus. Appl Environ Microbiol. 65: 2570-2576.

13. Lin X, Lee CG, Casale ES \& Shih JCH. 1995. Purification and characterization of a keratinase from a feather-degrading Bacillus licheniformis strain. Appl Environ Microbiol. 58(10): 3271-3275.

14. Raju AA, Chandrababu NK, Samivelu N, Rose C \& Rao NM. 1996. Eco-friendly enzymatic dehairing using extracellular proteases from a Bacillus species isolate. J Am Leather Chem Assoc. 91(5): 115-119.

15. Ichida JM, Krizova L, LeFevre CA, Keener HM, Elwell DL \& Burtt Jr EH. 2001. Bacterial inoculum enhances keratin degradation and biofilm formation in poultry compost. J Microbiol Methods. 47: 199-208.

16. Williams CM, Lee CG, Garlich JD \& Shih JCH. 1991. Evaluation of a bacterial feather fermentation product, feather-lysate, as a feed protein. Poultry Sci. 70(1): 85-94. 
17. Dalev P \& Neitchev V. 1991. Reactivity of alkaline proteinase to keratin and collagen containing substances. Appl Biochem Biotechnol. 27(2): 131-138.

18. Choi JM \& Nelson PV. 1996. Developing a slow-release nitrogen fertilizer from organic sources. 2. Using poultry feathers. J Am Soc Horticultural Sci. 121(4): 634-638.

19. Hoq MM, Siddiquee KAZ, Kawasaki H \& Seki T. 2005. Keratinolytic activity of some newly isolated Bacillus species. J Biol Sci. 5(2): 193-200.

20. Wang JJ \& Shih JCH. 1999. Fermentation production of keratinase from Bacillus licheniformis PWD-1 and a recombinant $B$. subtilis FDB-29. J Ind Microbiol Biotechnol. 22(6): 608-616.

21. Adinarayana K \& Ellaiah P. 2002. Response surface optimization of the critical medium components for the production of alkaline proteases by a newly isolated Bacillus sp. J Pharm Pharmaceut Sci. 5(3): 272-278.

22. Rahman A \& Gomes DJ. 2003. Optimization of medium ingredients for $\beta$-mannanase production by Aspergillus sp. isolated from commercial guar gum. Dhaka Univ J Biol Sci. 12(2): 153-164.

23. Bradford MM. 1976. A rapid and sensitive method for the quantitation of microgram quantities of protein utilizing the principle of proteindye binding. Appl Microbiol Biotechnol. 72: 248-254.

24. Griffin HL, Greene RV \& Cotta MA. 1992. Isolation and characterization of an alkaline protease from the marine shipworm bacterium. Curr Microbiol. 24: 111-117.

25. Ilias M, Barua S, Bhuiyan MU, Rahman A \& Hoq MM. 2005. Characteristics of proteases production by Brevibacilllus borstelensis MZK-6. Bangladesh J Microbiol. 22(2): 126-129.
26. Auden J, Gruner J, Nûesch J \& Knûsel F. 1967. Some statistical method in nutrient medium optimization. Pathol Microbiol. 30: 856-866.

27. Desrochers M, Jurasek L \& Koller J. 1980. Production of cellulase in shake flask culture of Schizophyllum commune: Optimization of the medium. TAPPI. 63: 161-167.

28. McDaniel LE, Bailey EG, Ethiraj S \& Andrews HP. 1976. Application of response surface optimization techniques to polyene macrolide fermentation studies in shake flasks. Dev Ind Microbiol. 17: 91-98.

29. Retzlaff G, Rust \& Waibel J. 1975. Die bestimmung optimaler Verhältisse. In Statistische Versuchsplanung: Planung naturwissengschaftlicher Experimente und ihre Auswertung mit statisschen Methoden (Retzlaff G, Rust G \& Waibel J eds), pp 141155. Hans Richarz Publications - Service, Sankt Augustin.

30. Asahi M, Lindquist R, Apodaca G, Epstein LW \& Mckerrows JH. 1985. Purification and characterization of major extra-cellular proteinase from Trichophyton rubrum. Biochemical J. 232: 139-144.

31. Taha IZ. 1998. Cloned Bacillus subtilis alkaline protease (apr A) gene showing high level of keratinolytic activity. J Appl Biotechnol Biochem. 70-72: 199-205.

32. Romanelli RA, Houston CW \& Barnett SM. 1975. Studies on thermophilic cellulolytic fungi. Appl Microbiol. 30: 276-281.

33. Williams CM, Shih JCH, Richter CS \& Mackenzie JR. 1990. Isolation, identification and characterization of feather degrading bacterium. J Appl Environ Microbiol. 56: 1509-1515.

34. Papadopoulos MC. 1989. Effect of processing on high-protein feedstuffs: A review. Biol Wastes. 29: 123-138. 